\title{
IMPLEMENTASI KEBIJAKAN STANDAR PELAYANAN MINIMAL (SPM) DALAM ORGANISASI PELAYANAN PUBLIK
}

\author{
Meri Enita Puspita Sari
}

\section{(Dosen Prodi Ilmu Pemerintahan UNRIKA BATAM}

\section{PENDAHULUAN}

Pelayanan publik yang optimal dan prima yang merupakan pengharapan dari seluruh masyarakat menjadi ukuran terhadap kinerja yang dilakukan oleh lembaga / instansi pelayanan publik. Penggambaran ketidapuasan masyarakat terhadap pelayanan publik maka akan selalu menjadi pembenahan pemerintah dalam mengevaluasi kebijakan-kebijakan yang telah diimplementasikan.

Implementasi kebijakan merupakan suatu proses melaksanakan keputusan kebijaksanaan (biasanya dalam bentuk Undang-Undang, Peraturan Pemerintah, Keputusan Peradilan, Perintah Eksekutif atau Dekrit Presiden) ${ }^{1}$. Sedangkan menurut Van Meter dan Van Horn (1975) merumuskan proses implementasi adalah tindakan-tindakan yang dilakukan baik oleh individuindividu / pejabat-pejabat atau kelompok-kelompok pemerintah atau swasta yang diarahkan pada tercapainya tujuan-tujuan yang telah digariskan dalam keputusan kebijaksanaan.

Istilah kebijakan (policy) yang dibedakan dari kata Kebijaksanaan (wisdom) maupun Kebajikan (virtues) merupakan prinsip atau cara betindak yang dipilih untuk mengarahkan pengambilan keputusan. Sedangkan menurut Ealau dan Prewitt (1973), kebijakan adalah sebuah ketetapan yang berlaku yang dicirikan oleh perilaku yang konsisten dan berulang, baik dari yang membuatnya maupun yag mentaatinya (yang terkena kebijakan itu). Dengan demikian dapat dinyatakan bahwa kebijakan adalah suatu ketetapan yang

${ }^{1}$ Dr,solichin Abdul Wahab,M.A. 1997. Analisis Kebijaksanaan. Malang : Bumi Aksara, hal 64. 
memuat prinsip-prinsip untuk mengarahakan cara-cara bertindak yang dibuat secara terencana dan kosisten dalam mencapai tujuan tertentu. Sehingga Standar Pelayanan Minimal (SPM), merupakan salah satu kebijakan pemerintah dalam hal peningkatan pelayanan publik.

\section{PEMBAHASAN}

Pelayanan Publik di Indonesia masih sangat rendah. Demikian salah satu kesimpulan Bank Dunia yang dilaporkan dalam World Development Report 2004 dan hasil penelitian Governance and Desentraliation Survey (GDS) 2002. ${ }^{2}$ Mengoptimalisasikan pelayanan pubik birokrasi memang bukan hal yang gampang, namun proses pembenahan manajemen publik secara bertahap bukan tidak mungkin bisa merubah budaya birokrasi pelayanan publik menjadi lebih baik lagi.

Usia kebijakan SPM telah mencapai 12 (duabelas) tahun yaitu sejak dikeluarkannya UU No. 22 Tahun 1999 yang kemudian ditindaklanjuti dengan PP No. 25 Tahun 2000 dan SE Mendagri No. 100/757/OTDA/2002 yang selanjutnya diteruskan dengan UU No. 32 Tahun 2004 yang dioperasionalisasikan dengan PP No. 65 Tahun 2005 dan Permendagri No. 6 Tahun 2007, namun kebijakan tersebut belum mencapai hasil yang menggembirakan mengingat berbagai faktor yang mempengaruhi. Salah satu faktor yang dianggap sangat berpengaruh adalah belum lengkapnya konsep SPM (dalam proses pencarian bentuk) disamping belum adanya kesamaan pemahaman antara perumus kebijakan di tingkat Pusat dan pelaksana kebijakan di tingkat Daerah. Manajemen yang baik dan sistematis juga ikut berperan dalam standar pelayanan minimal.

Sedangkan disisi lain ada manajemen yang merupakan proses universal, tetapi jenis organisasi dan lingkungan yang berbeda menuntut strategi manajemen yang berbeda, dimana hal ini makin menampak diantara organisasi publik dan swasta. Pelayanan merupakan proses pemenuhan kebutuhan melalui aktivitas orang lain secara langsung. Pelayanan yang diperlukan manusia pada dasarnya ada dua jenis, yaitu layanan fisik yang 
sifanya pribadi sebagai manusia dan layanan administratif yang diberikan oleh orang lain selaku anggota orgainisasi, baik itu Organisasi Massa atau Negara. ${ }^{3}$ Hal ini dapat dilihat dengan diberlakukannya Undang-Undang Otonomi daerah tahun 2004 yang terdiri dari Undang-Undang Nomor 32 Tahun 2004 tentang Pemerintahan Daerah dan Undang-Undang Nomor 33 Tahun 2004 Tentang Perimbangan Keuangan Antara Pusat dan Pemerintahan Daerah. Dalam Undang-Undang No.32 Tahun 2004, yang terdapat dalam pasal 16 disebutkan bahwa:

1. Hubungan dalam bidang pelayanan umum antara Pemerintah dan Pemerintahan Daerah sebagaimana dimaksud dalam pasal 2 ayat (40) dan Ayat (5) meliputi :

a. Kewenangan, tanggung jawab, dan penentuan standar pelayanan minimal.

b. Pengalokasian pendanaan pelayanan umum yang menjadi kewenangan daerah; dan

c. Fasilitas pelaksanaan kerjasama antar pemerintahan daerah dalam penyelenggaraan pelayanan umum.

2. Hubungan dalam bidang pelayanan umum antar pemerintahan daerah sebagaimana dimaksud dalam pasal 2 ayat (4) dan ayat (5) meliputi :

a. Pelaksanaan bidang pelayanan umum yang menjadi kewenangan daerah.

b. Kerja sama antar Pemerintahan Daerah dalam penyelanggaraan pelayananan umum; dan

c. Hubungan dalam bidang pelayanan umum sebagaimana diaksud pada ayat (1) dan ayat (2) diatur dalam peraturan perundangundangan. ${ }^{4}$

Dengan adanya otonomi daerah maka akan ada kebijakan desentralisasi daerah, seperti desentralisasi dibidang pendidikan, perizinan dan kesehatan. Pemerintah sebagai pemberi pelayanan utama terhadap masyarakat harus memiliki kebijakan yang sesuai dengan kondisi dan situasi yang ada pada saat ini. Desentralisasi menyebabkan perubahan besar dalam

3 Moenir, 1992. Manajemen Pelayanan Umum di Indonesia. Jakarta : Bumi Aksara, hal 17.

${ }^{4}$ Undang-undang No 32 tentang Pemerintahan Daerah yang tedapat dalam pasal 16 ayat 1 dan 2 
tatanan pemerintah sehingga tejadi juga perubahan peran dan fungsi birokrasi mulai dari tingkat pusat sampai ke daerah. Perubahan yang mendasar itu memerlukan juga pengembangan kebijakan yang mendukung penerapan desentralisasi dalam mewujudkan pembangunan pendidikan sesuai kebutuhan daerah dan diselenggarakan secara efektif, efisien dan berkualitas.

Undang-undang No. 32 tahun 2004 tentang pemerintahan daerah memberikan nuansa khusus desentralisasi kepada daerah, di mana kewenangan daerah mencakup kewenangan dalam seluruh bidang pemerintahan kecuali kewenangan bidang politik luar negeri, pertahanan keamanan, peradilan, moneter dan fiskal, agama serta kewenangan bidang lain yang bersifat nasional. Adapun 3 Peranan utama Pemerintah : (1) Peran sebagai pembiaya (fasilitator), Pemerintahah bertanggung jawab dalam penyediaan dana atau membuat sistem pelayanan yang berkualitas yang dapat diakses bagi masyarakat miskin, (2) Peran sebagai Pelaksana pelayanan, Pemerintah bertanggung jawab adalam menyediakan pelayanan yang berkualitas, (3) Peran sebagai Regulator, Menjamin tersediannya lembaga pelayanan kesehatan pemerintah dan swasta yang aman/ patient safety. Dengan diberlakukannya Undang-Undang otonomi daerah diatas, maka diharapkan pemerintah khususnya pemerintah daerah dapat memberikan standar pelayanan minimal bagi masyarakat umum demi memberikan kepuasan dalam masyarakat. Karena pemerintah merupakan pemberi pelayanan utama dalam masyarakat.

Berdasarkan Peraturan Pemerintah Republik Indonesia No.65 tahun 2005 tentang Pedoman Penyusunan dan Penerapan Standar Pelayanan minimal yang merupakan tindak lanjut dari Surat Edaran Mentri Dalam Negeri Nomor 100/757/OTDA Tahun 2002 menyatakan bahwa ketentuan tentang Standar Pelayanan Minimal (SPM) yang harus dipenuhi oleh setiap Pemerintah Kabupaten dan kota dalam penyediaan pelayanan publik. ${ }^{5}$ Ini merupakan hal yang baru dalam sejarah pelaksanaan otonomi daerah di Indonesia. Didalam Surat Edaran mentri Dalam negeri Nomor 100/757/OTDA, tanggal 8 juli 2002 dituliskan bahwa SE Mendagri ini dirumuskan dengan maksud sebagai dasar

${ }^{5}$ Ratmito dan Atik Septi winarsih, 2005. Manajemen Pelayanan. Yogyakarta: Pustaka Pelajar, hal. 255. 
penyelenggaraan kewenangan wajib daerah dan pengguna Standar pelayanan Minimal agar masing-masing Institusi Pemerintah memiliki kesamaan persepsi dan pemahaman serta tidak lanjut dalam penyelanggaraan Standar pelayanan Minimal.

Selanjutnya didalam Peraturan Pemerintah Nomor 65 tahun 2005 Tentang Pedoman Peyusunan dan Penerapan Standar Pelayanan minimal ditegaskan bahwa Pedoman Penyusunan dan Penerapan SPM menjadi acuan dalam penyusunan SPM oleh Menteri / Pimpinan Lembaga Pemerintah Non Departeman dan dalam penerapannya oleh Pemerintah Provinsi dan pemerintahan Kabupaten/Kota. SPM disusun dan diterapkan dalam rangka penyelenggaraan urusan wajib Pemerintahan Daerah Provinsi dan Pemerintahan Daerah kabupaten / kota yang berkaitan dengan pelayanan daerah sesuai dengan peraturan perundang-undangan.

\section{Manajemen Pelayanan Publik}

Menurut Keputusan MENPAN Nomor 63/2003 mendefinisikan bahwa Manajemen Pelayanan Publik adalah segala bentuk pelayanan yang dilaksanakan oleh instansi Pemerintah di Pusat, di Daerah dan di lingkungan Badan Usaha Milik Negara atau Badan Usaha Milik Daerah dalam bentuk barang dan atau jasa, baik dalam rangka upaya pemenuhan kebutuhan masyarakat maupun dalam rangka pelaksanaan ketentuan peraturan perundang-undangan.

Sehingga manajemen pelayanan publik atau manajemen pelayanan umum dapat didefinisikan sebagai segala bentuk jasa pelayanan baik dalam bentuk barang publik yang pada prinsipnya menjadi tanggung jawab dan dilaksanakan oleh instansi pemerintah di Pusat. di Daerah, dan di Lingkungan Badan Usaha Milik Negara atau badan Usaha Milik Daerah, dalam rangka upaya pemenuhan kebutuhan masyarakat maupun dalam rangka pelaksanaan ketentuan peraturan perundangundangan.

Adapun tiga jenis pelayanan publik atau pelayanan umum, yaitu : 
1. Pelayanan Publik yang diselenggarakan oleh Privat. Pelayanan ini menyediakan semua penyediaan barang atau jasa publik yang diselenggarakan oleh swasta.

2. Pelayanan Publik yang diselenggarakan oleh Pemerintah dan bersifat primer. Pelayanan ini menyediakan semua penyediaan barang/ jasa publik yang diselenggrakan oleh Pemerintah yang didalamnya Pemerintah merupakan satu-satunya penyelenggara dan penggunan/ klien mau tidak mau harus memanfaatkannya.

3. Pelayanan Publik yang diselenggrakan oleh Pemerintah dan bersifat sekunder. Pelayanan ini menyediakan segala bentuk penyediaan barang/jasa Publik yang dselenggaraka oleh Pmerintah, tetapi yang didalamnya pengguna/klien tidak harus mempergunakannya karena adanya beberapa penyelenggara pelayanan.

Pemberian pelayanan publik baik dalam bentuk pelayanan primer maupun sekunder merupakan urusan wajib yang harus dilaksanakan oleh pemerintah sebagai pemberi pelayanan, sehingga setiap penyelenggara pelayanan publik harus memiliki standar pelayanan dan dipublikasikan sebagai jaminan adanya kepastian bagi penerima pelayanan. Standar pelayanan merupakan ukuran yang dibakukan dalam penyelenggaraan pelayanan publik yang wajib ditaati oleh pemberi dan atau penerima pelayanan, sehingga manajemen pelayanan publik dapat berjalan secara optimal.

Manajemen pelayanan publik yang baik hanya akan dapat diwujudkan apabila penguatan posisi tawar penggunan jasa pelayanan mendapatkan prioritas utama. Dengan demikian, pengguna jasa diletakkan dipusat yang mendapatkan dukungan dari (a) system pelayanan yang mengutamakan kepentingan masyarakat, khusunya penggunan jasa, (b) kultur pelayanan dalam organisasi penyelenggaraan pelayanan dan (c) sumber daya manusia yang berorientasi kepada kepentingan pengguna jasa. Hubungan antara penyelenggara pelayanan dan penggunan jasa pelayanan harus juga diimbangi dengan berfungsinya mekanisme 'voice' yang diperankan oleh media, lembaga Swadaya Masyarakat, Organisasi Profesi dan Ombudsmen atau Lembaga Banding. 


\section{Kebijakan Standar Pelayanan Minimal (SPM)}

Kebijakan standar pelayanan minimal dibuat berdasarkan Surat Edaran Mentri Dalam Negeri Nomor 100/757/OTDA, tanggal 8 juli 2002 dituliskan bahwa SE Mendagri ini dirumuskan dengan maksud sebagai dasar penyelenggaraan kewenangan wajib daerah dan penggunaan standar pelayanan minimal agar masing-masing institusi pemerintah memiliki kesamaan persepsi dan pemahamam serta tindak lanjut dalam penyelenggaraan Standar Pelayanan Minimal.

Selanjutnya dalam peraturan pemerintah Nomor 65 tahun 2005 Tentang Pedoman Penyusunan dan Penerapan Standar pelayanan Mnimal ditegaskan bahwa pedoman penyusunan dan penerapan SPM menjadi acuan dalam penyusunan SPM oleh Mentri/Pimpinan Lembaga Pemerintah Non Departemen dan dalam penerapannya oleh pemerintah provinsi dan Pemerintahan Kabupaten/kota. SPM disusun dan diterapkan dalam rangka penyelenggaraan urusan wajib Pemerintahan daerah kabupaten/kota yang berkaitan dengan pelayanan dasar sesuai dengan peraturan perundang-undangan.

Di dalam Peraturan Pemerintah Nomor 65 Tahun 2005, ada beberapa pengertian dasar yang harus dipahami, yaitu :

a. Pemerintah Pusat, yang didalam PP selanjutnya disebut pemerintah adalah Presiden Republik ndonesia yang memegang Kekuasaan pemerintahan Negara RI sebagaimana dimaksu dalam UUD Negara RI Tahun 1945.

b. Daerah adalah kesatuan masyarakat hokum yang mempunyai batasbatas wilayah yang berwenang mengatur dan mengurus urusan pemerintah dan kepentingan masyarakat setempat menurut prakarsa sendiri berdasarkan aspirai masyarakat dalam system Negara Kesatuan RI.

c. Pemerintah Daerah adalah penyelenggara urusan pemerintahan oleh Pemerintah Daerah dan DPRD menurut asas otonomi dan tugas pembantuan dengan prinsip otonomi seluas-luasnya dalm system dan prinsip Negara Kesatuan Ri sebagimana dimaksud dalam UUD Negara RI Tahun 1945. 
d. Pemerintah Negara adah Gubernur, Bupati, Walikta dan Perangkat daerah sebagai Unsur penyelenggara Pemerintahan Daerah.

e. Urusan wajib adalah urusan Pemerintahan yang berkaitan dengan hak dan pelayanan dasar warga Negara yang penyelenggaraannya diwajibkan oleh peraturan perundang-undangan kepada daerah untuk perlindungan hak konstitusional, kepentingan nasional, kesejahteraan masyarakat, serta ketentraman dan ketertiban umum dalam rangka menjaga keutuhan Negara Kesatuan RI serta pemenuhan komitmen nasional yang berhuungan dengan perjanjian dan konvensi Internasioal.

f. Standar Pelayanan Minimal yang selanjutnya disingkat SPM adalah ketentuan tentang jenis dan mutu pelayanan dasar yang merupakan urusan wajib daerah yang berhak diperoleh setiap warga secara minimal.

g. Indikator SPM adalah tolak ukur prestrasi kuantitatif dan kualitatif yang digunakan untuk menggambarkan besaran sasaran yang hendak dipenuhi dalam pencapaian suatu SPM tertentu, berupa masukan, proses, hasil dan/atau manfaat pelayanan.

h. Pelayanan Dasar adalah jenis pelayanan pulik yang mendasar dan mutlak untuk memenuhi kebutuhan masyarakat dalam kehidupan sosial, ekonomi dan pemerintahan.

i. Dewan Pertimbangan Otonomi Daerah selanjutnya disingkat DPOD adalah dewanyang bertugas memberikan sasaran dan pertimbangan kepada Presiden terhadap kebijakan otonomi daerah.

Dalam pengertian dasar tersebut sangat jelas terlihat bahwa SPM sangat diperlukan oleh sebuah instansi dalam menerapkan dan menjalankan fungsinya terutama dalam melayani masyarakat. Dinas Kesehatan, Dinas Perizinan, Dinas Pendidikan maupun Instansi-instansi pelayanan publik lainnya diharapkan memiliki Standar Pelayanan Minimal (SPM) sesuai dengan Peraturan Pemerintah yang telah di Implementasikan dan dituangakan dalam Peraturan Pemerintah Nomor 65 tahun 2005 dan dalam penerapan standar pelayanan minimal didalam PP Nomor 65 Tahun 2005 diatur hal-hal sebagai berikut : 
1. Pemerintah Daerah menerapkan Standar Pelayanan Minimal (SPM) sesuai dengan ketentuan yang diatur dalam peraturan Menteri.

2. Standar Pelayanan Minimal (SPM) yang telah diterapkan Pemerintah menjadi salah satu acuan bagi Pemerintahan daerah untuk menyususn perencanaan dan penganggaran penyelenggaran Pemerintahan daerah.

3. Pemerintah Daerah menyususn rencana pencapaian Standar Pelayanan Minimal (SPM) yang memuat target tahunan pencapaian Standar Pelayanan Minimal (SPM) dengan mengacu pada batas waktu pencapaian Standar Pelayanan Minimal (SPM) sesuai dengan peraturan Menteri.

4. Rencana pencapaian SPM tersebut dituangkan dalam Rencana Pembangunan Jangka Menengah Daerah (RPJMD) dan Rencana Strategis Satuan kerja Perangkat daerah ( Renstra SKPD).

5. Target tahunan pecapaian SPM tersebut dituangkan kedalam Rencana Kerja Pemerintah Daerah (RKPD), Rencana Kerja Satuan Kerja Perangkat Daerah (Renja SKPD), Kebijakan Umum Anggaran (KUA), Rencana Kerja dan Anggaran Satuan Kerja Perangkat Daerah (RKASKPD) sesuai klasifikasi belanja daerah dengan mempertimbangkan kemampuan keuangan daerah.

6. Penyusunan rencana pencapaian SPM dan anggaran kegiatan yang terkait dengan pencapaian SPM dilakukan berdasarkan analisis kemampuan dan potensi daerah denganmengacu pada pedomam yang ditetapkan oleh Mnetri dalam Negeri.

7. Rencana pencapaian target tahunan SPM serta ralisasinya diinformasikan kepada masyarakat sesuai peraturan perundangundangan.

8. Pemerintah daerah mengakomondasikan pengelolaan data dan informasi penerapan SPM kedalam sistem informasi daerah yang dilaksanakan sesuai dengan peraturan perundang-undangan.

9. Dalam rangka pelaksnaan urusan pemerintahan yang mengakibatkan dampak lintas daerah dan / atau untuk menciptakan efisiensi, daerah wajib mengelola pelayanan publik secara bersama dengan daerah disekitarnya sesuai peraturan perundang-undangan. 
10. Dalam pengelolaan pelayanan dasar secara bersama sebagai bagian dari pelayanan publik, rencana pencapaian SPM perlu disepakati bersama dan dijadikan sebagai dasar dalam merencanakan dan menganggarkan kontribusi masing-masing daerah.

11. Dalam upaya pencapaian SPM, pemerintah daerah dapat bekerja sama dengan pihak Swasta. ${ }^{6}$

Dengan adanya penerapan Standar Pelayanan Minimal atau disingkat dengan SPM, mampu meningkatkan sistem pelayanan prima terhadap masyarakat karena terangkat dari keluhan-keluhan masyarakat yang menganggap bahwa Birokrasi Indonesia terkesan "Berbelit-belit". Organisasi Pelayanan Publik yang utama besentuhan langsung dengan masyarakat seperti di bidang Kesehatan, Pendidikan dan maupun Perizinan wajib menyusun Standar Pelayanan Minimal demi kepuasan masyarakat dan peningkatan Efektivitas dan Efisiensi demi tercapainya Good Governance karena sudah bukan rahasia lagi bahwa saat ini pelayanan publik di Indonesia secara umum masih sangat buruk. Berbagai peraturan yang dibuat dalam rangka meningkatkan kualitas pelayanan publik seolah tidak memberi dampak apapun kepada masyarakat. Berbagai tindakan menyimpang dari aparat pelayan publik (public servant) tidak juga berkurang, bahkan cenderung menjadi-jadi. Terangkat dari hal tersebut maka harus mengarah kepada Prinsip Pelayanan Publik, dimana Pelayanan Publik yang diharapkan seluruh masyarakat Indonesia.

\section{KESIMPULAN}

Salah satu fungsi sekaligus tugas utama birokrasi publik (pemerintah) adalah memberikan pelayanan sebaik-baiknya kepada masyarakat (pelayanan prima). Dalam teori pelayanan publik, pelayanan prima (excellent service) dapat diwujudkan jika ada standar pelayanan minimal (SPM). Standar Pelayanan Minimal (SPM) adalah tolok ukur yang dipergunakan sebagai pedoman penyelenggaraan pelayanan dan acuan penilaian kualitas pelayanan

${ }^{6}$ Ratminto \& Atik Septi WInarsih, 2005. Manajemen Pelayanan hal 261. Yogyakrta : Pustaka Pelajar 
sebagai komitmen atau janji dari penyelenggara negara kepada masyarakat untuk memberikan pelayanan yang berkualitas. Dalam Rancangan Undangundang Pelayanan Publik, standar pelayanan ini setidaknya-tidaknya berisi tentang: dasar hukum, persyaratan, prosedur pelayanan, waktu penyelesaian, biaya pelayanan, produk pelayanan, sarana dan prasarana, kompetensi petugas pemberi pelayanan, pengawasan intern, penanganan pengaduan, saran dan masukan, dan jaminan pelayanan.

Khusus menyangkut masalah tarif atau biaya pelayanan, maka kejelasan tentang berapa jumlah uang yang harus dibayar dan kepada siapa masyarakat membayar menjadi sangat penting dalam kaitannya dengan kepuasan masyarakat yang dilayani. Kepuasan masyarakat ini merupakan salah satu ukuran berkualitas atau tidaknya pelayanan publik yang diberikan oleh aparat birokrasi pemerintah daerah atau organisasi pelayanan publik lainnya. Oleh karena itu, perbaikan pelayanan publik mutlak diperlukan agar image buruk masayarakt kepada pemerintah dapat diperbaiki, karena dengan perbaikan kualitas pelayanan publik yang semakin baik, dapat mempengaruhi kepuasan masayarkat sehingga kepercayaan masyarakat terhadap pemerintah dapat dibangun kembali. Bersandarkan pada SPM ini, maka seharusnya pelayanan publik yang diberikan (pelayanan prima) oleh birokrasi pemerintah daerah bercirikan: kesederhanaan, kejelasan, kepastian dan tepat waktu, akurasi, bertanggung jawab, kelengkapan sarana dan prasarana, kemudahan akses, kejujuran, kecermatan, kedisiplinan, kesopanan, dan keramahan, keamanan dan kenyamanan. Inilah potret pelayanan publik dambaan setiap warga masyarakat Indonesia setelah munculnya gerakan reformasi 1998.

\section{DAFTAR PUSTAKA}

\section{Buku :}

Moenir, 1992. Manajemen Pelayanan Umum di Indonesia. Jakarta : Bumi Aksara. 
Peraturan Pemerintah Nomor 65 tahun 2005 Tentang Pedoman Peyusunan dan Penerapan Standar Pelayanan minimal.

Ratmito dan Atik Septi winarsih, 2005. Manajemen Pelayanan. Yogyakarta: Pustaka Pelajar.

Sinambela, Lijan Poltak, 2006, Reformasi Pelayanan Publik. Teori, Kebijakan, dan Implementasi. Jakarta : Bumi Aksara.

Undang-undang No 32 tentang Pemerintahan Daerah.

Wahab, Solichin Abdul, 1997, Analisis Kebijaksanaan. Malang : Bumi Aksara.

Internet :

http://www.unila.ac.id/ fisip-admneg/mambo, Ilmu Administrasi Negara FISIP Unila, Tanggal 26 January 2008.

1.1 